\title{
Perceptual metaphors in the representation of ballroom dancing: cross-cultural approach
}

\author{
M. Siedakova \\ Zaporizhzhia National University, Zaporizhzhia, Ukraine \\ Corresponding author. E-mail: margaritasedakova@hotmail.com \\ Paper received 11.11.19; Accepted for publication 21.11.19.
}

\begin{abstract}
https://doi.org/10.31174/SEND-Ph2019-212VII63-16
\end{abstract}
\begin{abstract}
The purpose of this article is to discuss the role of metaphors in the representation of ballroom dancing through different languages and cultures. The paper deals with the formation of multimodal images embodying ballroom dance as the complex phenomenon of choreographic discourse. To examine perceptual metaphors, 200 pieces of English, German and Russian choreographic texts relating to ballroom dancing were analyzed by contextual method. Conceptual and comparative methods were employed to treat 300 metaphorical expressions and study images of ballroom dance encoded by linguistic means.
\end{abstract}

Keywords: perceptual metaphor, comparative method, modality, choreographic discourse.

Introduction. Studying metaphors is among most topical issues for the last few decades in linguistics. Since Aristotle's Rhetoric, metaphor has been treated in terms of stylistics as a device of poetic imagination and rhetorical flourish. However, modern science approaches it differently to suggest that metaphor is a notion of practical use of language and plays a significant role in the processes of thinking, perception, efficient performance of the conceptual system [2, p.5].

Cognitivists advanced our knowledge about the nature and mechanisms of metaphor. Having found out that "the most of our ordinary conceptual system is metaphorical in nature" $[24$, p.4], they then proceeded to study the use of metaphors in different types of discourses conditioned by numerous factors such as physical environment, social situation, cultural situation, history-memory, interests and concepts. "We would probably say that the world is used metaphorically in order to achieve some artistic and rhetorical effect" [22, p.9]

Remarkable studies [6] on metaphor as an element of professional discourse shed more light on ways and degrees of expressivity in various fields of professional communication. Some linguists focused on the interpretation of metaphor as a result of an individual's creative efforts.

In cognitive terms, metaphor is created by conceptualization of a particular cognitive domain (the target of metaphorisation) in terms of another cognitive domain (the source of metaphorisation). Cognitive linguists agree that namings referring to sensory perception are also used metaphorically to indicate specific aspects of thought or knowledge [23, 38]. People tend to create metaphors in real communicative situations relying upon their experience, cultural and cognitive preferences. Cognitive approach explains metaphor as mechanism for the meaning formation that is realized in discourse.

Due to their powerful emotional impact, metaphors are significant in ballroom dancing communication. They also play a crucial role in representing feelings and emotions of performers, their trainers, and spectators. One of the key functions of the perceptual metaphors is to create vivid images of ballroom dancing movements. With the help of metaphorical models human consciousness formulates its own meaningful experience: rumba - love, tango - passion, cha cha cha - flirtation etc. [26, p. 37].
Hypothesis and research question. It is hypothesized that perceptual metaphors embodying ballroom dancing exhibit cross-cultural and cross-linguistic features as well as specificity. The latter is determined by the type of dance the discourse is dealing with and cultural priorities of speakers.

Methods and materials. To examine perceptual metaphors, 200 pieces of English, German and Russian choreographic texts relating to ballroom dancing were analyzed by contextual method. Conceptual and comparative methods were employed to treat 300 metaphorical expressions and study images of ballroom dance encoded by the linguistic means of genetically close (English and German) and distant (two Germanic and one Slavonic) languages.

Results and discussion. Cognitive metaphors arise due to conceptualised knowledge of the world and our perceptual experience. There are five modes of perception: sight, touch, smell, taste and hearing. We are able to associate different entities and establish some visual, acoustic, olfactory, kinesthetic and gustative likeness or similarities in them.

The image representation of ballroom dance is mainly achieved by metaphors based on visual images. It can be explained by the dominance of visual modality in the process of dance movements' sensory perception. Visual images are created by various lexical means such as adjectives with dimensional meanings (E. long, Rus. длинный: "measuring or covering a great length or distance”, E. wide, Rus. широкий "covering a large area"); adjectives and nouns denoting shapes and forms (E.wavelike: "having a waving motion", E. wave, Rus. волна: "to move freely and gently back and forth or up and down, as by the action of air currents"), verbs and participles denoting movements (E. gliding, Rus. скользящий "to move smoothly and continuously along”), nouns referring objects of art (Ger. Bild, E. picture, Rus. картинка "a visual representation of a person, object or scene"), participles with directional meanings (E. reverse "turning in an opposite position"). Let us consider several examples.

The performance of waltz is represented with the help of words relating to plain, slow and continuous and/or repetitive movements ("long gliding steps are used in modern waltz" [37, p.86], "All the joints are loose and the knees always flexed, allowing the dancers to per- 
form wavelike movements" [10, p.90] "gentle swinging waltz" [8, p.43]).

Such linguistic means contribute to the formation of the image of WAVE: "some people say that wavelike movement... of dancers represents the water... [14, p.84]). The image of water moving across the surface and capturing space ("The big dance halls...were nightly the scene of couples threading their way round the floor with the long gliding steps" [4, p.124], "a wide dance step" [5, p. 235]) produces the atmosphere of charm, magic, beauty, lightness and peace ("The feeling of lightness is created in this sequence emphasizes a fairy-tale quality..." [3, p. 25]).

It is noteworthy that the same image is actualized in the ballroom dance terminology: the terms E. Reverse Wave and E. Extended Reverse Wave are made up of extended meaning "enlarged" and reverse meaning "to exchange the position or function". This dance technique requires performers to exchange their positions and functions: a lady dancer goes forward whereas a man dancer goes backward. The terminology emphasizes the importance of wavelike movements for professional, highstandard performance.

Similar descriptions are found in the Russian-speaking dance discourse:"Шаги венского вальса скользящие” [1, p. 58], “движения танияа как бы исчезали и вновь нарождались в волнах ... вальса" [36, р. 108], “маги скользящие, протяжные...первыц иаг - самый длинный" [1, р.55], "по мере выполнения этого широкого шага...” [32, p. 37].

Another visual image of ballroom dancing shared by all the types of discourse in question is DANCE=PICTURE: E. "Dance is a wonderful threedimensional picture" [18] (< picture "sufficiently full in characterization and representation of events to be believable; having length, breadth and depth"); Ger. "Tanz als Bild" [19, p.22], "Tanz im Bild..." [21, p.260], “... Malen ...als frühe Wurzeln des Tanzes" [21, p.284]; Rus. "прекрасная картинка" [11]. In these verbalizations the art of painting collaborates with the art of dancing.

To sum up, visual images of ballroom dancing appear in the professional discourse expressed by different languages. The results suggest that in the English- and Russian-speaking cultures, the image of wave prevails over the image of picture whereas the German-speaking culture conceptualizes ballroom dancing rather as a picture.

Gustatory images are created in choreographic discourse with the help of adjectives denoting taste (E. delicious, Rus. вкусно "highly pleasing to the senses, especially to taste or smell", E. sweet "having a pleasant taste"), participles meaning various ways of processing food (E. melting, Ger. verschmelzend "to become liquefied by warmth or heat") and names of ingredients (E. ingredients, Ger. Komponent "thing or quality that is necessary to make something successful").

Gustatory images of ballroom dancing in the Englishspeaking discourse are embodied with the help of such gastronomic metaphors: "... try to keep 100\% tango ingredients in there at all times" [33, p.50], "No one book can provide all the ingredients necessary for the production of dance..." [34, p.10], "O,that sweet, delicious waltz" [12, p.75], "What a deli- cious waltz that was" [28, p. 10], "It is a slow sweet waltz [9, p. 89]", "In dance...her arms are melting onto me" [18]. Ballroom dancing is conceptualized as TASTY FOOD which has a distinctive flavor: "...the internet, including discussion forums, videos on YouTube, websites selling costumes and instructional DVDs are all important in giving ballroom dancing its global flavour" [17, p.4 ], where flavour means " $a$ distinctive taste of a food". Dance is represented as a high quality product "Keep learn, keep practice, keep perform in creation of beautiful art product-DANCE”.

The same gustatory images are found in the Germanspeaking dance discourse: "Tango besteht aus drei Komponenten: der Musik, dem Text und dem Tanz” [20, p. 88], “...die beiden Komponenten sind im Tanz vereint" [29, p.42] and in the way of processing the food: "Der Tango...ist der Tanz der Berührung und der verschmelzenden Körper" [39, 2017].The taste of dance is also explicit in the Russian-speaking discourse “Танец было сделано до мелочей, так вкусно, каждое движение, каждый взгляд...” [35]. Although gustatory images are efficiently created my means of different languages, the Russian- and English-speaking cultures appeal to the image of DANCE=TASTY FOOD and the German-speaking dance discourse attracts the image of DANCE=TASTY DISH.

Metaphors based on tactile images are created with the help of adjectives denoting feelings (E.sharp, Ger. scharf "having a fine edge or point", E. smooth "completely flat and even, without lumps and holes”, Rus. жсаркий "having a high temperature, producing heat”). Let us consider some examples.

Perceptual metaphors enable opposite tactile images depending on the type of dance: SMTH. POINTED E. "sharp arm and hand movements..." [40, p.12], "The dance moves are very sharp with quick head turns" [27, p.30]; SMTH. PERFECTLY REGULAR — E. "You will know how to do a smooth waltz" [7, p. 172], "yet ballroom dancing offers more than just smooth moves", "ballroom dancing offers...smooth moves" [16, p.4], “...smooth dance with fluid movements"). The German-speaking dance discourse also appeals to tactile modality: "Ich bin so begeistert über die erstaunlich scharfe Empfindung seiner Arme und des ganzen Körpers, die starken Anregungen der scharfen Bewegungen der Finger in der einfachen Tanztechnik..."[31, p. 162]. The opposite images of THIN, POINTED OBJECT and FLAT SURFACE INVOLVING THE SAME PATTERN OR AMOUNT.

The Russian-speaking choreographic discourse appeals to a different tactile image - DANCE=FEVER: Rus. “жаркие танцьь”, “жаркий ча-ча-ча" [15] that characterizes dance as something passionate, flaming from the point of view of discourse participants.

The perceptual metaphors convince that the ballroom dance has a powerful emotional impact on the performers as well as on audience: "when two humans are connected through art, they end up making one magical dance" [25]. Dancers experience the whole range of emotions while performing on the floor: " $a$ dancing pair expresses relationship emotions in all degrees; attraction, combat, flirtation, betrayal, rejection, longing..." [13, p. 53]. Viewers in their turn admit that they 
observe a special story that is told by dancers with the help of movements: "...dance has always been, and always will be a form of communication" [30, p.8], "Dancers do not just listen to the music; they feel the rhythms and tell a story with their movements" [40, p.7].

Concluding remarks. Perceptual metaphors play an important role in the processes of encoding knowledge. Numerous verbal means employed in dance discourse create perceptual metaphors with positive semantic load. These perceptual metaphors reveal the art of ballroom dancing in all its multiplicity. Cross-cultural metaphors of ballroom dance are mainly created by appealing to the three modalities leading to the visual images DANCE=WAVE and DANCE=PICTURE, the tactile images DANCE=POINTED OBJECT and DANCE=REGULA ROBJECT, the gustatory images of DANCE=TASTY FOOD; DISH. Visual and gustatory images of ballroom dancing are common in all the types of discourse in question whereas tactile image DANCE=FEVER is more characteristic of the Germanspeaking discourse.

\section{REFERENCES}

1. Aleksandrova N.A. Dances of all times and folks. 2018. p.88

2. Arutunova N.D. Metaphor and Discourse. 1990

3. Balanchine G., Mason F. Balanchine's Festival of Ballet. 1978. p.838

4. Bradley J. Dancing Times. 1945. p. 233

5. Brandstetter G. Poetics of Dance: Body, Image and Space in the Historical Avant-gardes, Oxford University Press. 2015. p.432

6. Cameron L. Metaphor in Educational Discourse. 2003

7. Cassidy D. Waltz This Way. Penguin. 2012. p.352

8. Chagy J. Clavier. Instrumental Company. 1978. p.127

9. Clement C. Opera, Or, The Undoing of Women. 1997. p.198

10. Cohen S.I. International Encyclopedia of Dance: a Project of Dance Perspectives Foundations, Inc. Oxford University Press. 1998. p.635

11. Dancing with the stars https://www.youtube.com/watch?v=AlJfMBxmTsw

12. Douglas A. Kept His Trust, Or, The Doctor's Household: The Record of a Noble Life, Cameron Ferguson. 1868. p.317

13. Drake-Boyt E. Latin Dance. ABC-CLIO. 2011. p.161

14. Edrich C. The Joy of Dance: For Those Who Have Rhythm in Their Feet. 2015. p.160

15. Evening Moscow. Journal №40 (826)

16. Freese J. Ballroom Dancing. Capstone. 2007. p.32

17. Harman V. The Sexual Politics of Ballroom Dancing. Springer. 2018. p.176

18. Hilton M. Waltz Lecture with Karen Hilton. Part 1. Video https://www.youtube.com/watch?v=ui7jHsy_Jzs

19. Keuchen M. Tanz und Religion: theologische Perspektiven.Verlag Otto Lembeck. 2008. S.245

20. Kimpfe V. Tango als Ausdruck der Melancholie in der modernen Gesellschaft. 2008. S.104

21. Klein G. Tanz, Bild, Medien. LIT Verlag Munster. 200 S. 284

22. Kövecses Z., Metaphor. http:// www. bowlib. bowenuniversityedu. org/joomla/ index2.php?option $=$ comdocman \& task $=$ doc_view $\&$ gid $=1926 \& I$ temid $=37$
23. Lakoff G. Women, Fire and Dangerous Things: What Categories Reveal About The Mind. University of Chicago Press. 1987. p. 632

24. Lakoff G., Johnson M. Metaphors We Live by. 2008. p.276

25. Lapaeva D. Elements of a Remarkable Dance Couple. Tips from the PROS. Dancesportlife. Nov.16, 2017.

26. Marion S. Johnathan. Ballroom: Culture and Costume in Competitive Dance. Berg. 2008. p.224

27. Morgan J. Ballroom Dancing Handbook: Unlock the Mysteries of Ballroom Dancing. Lulu Press Inc. 2015

28. Mrs. Alexander. Kate Vernon. 2019. p.120

29. Mühlpforte N. Die Auswirkungen von kreativen Tanzunterricht auf die Graphomotorik von Erstklässlern. Peter Lang. 2009. S.372

30. Musmon M. Latin and Carebean Dance. Inface Publishing. 2010. p. 120

31. Peter F.M. Der Tanzer Harald Kreutzberg. Ed. Hentrich, 1997. S. 240

32. Pogorelov V. Ballroom Dances. Slow Waltz. Part 1. 2018. p.95

33. Saunders J. Text. Practice. Performance. Center for Intercultural Studies in Folklore and Ethnomusicology. 2000. p.120

34. Smith-Autard M.J. Dance Composition: A practical guide to creative success in dance making. Bloomsbury Publishing. 2015. p. 256

35. So You Think You Can Dance. https://www.youtube.com/watch?v=QRqXmGDrUHk

36. Soviet Union Cultural Boundaries. Culture and Life. 1978

37. Stetson B. Introducing The Waltz. History. Steps. Etiquette. Read Books Ltd. 2016. p.86

38. Sweetser E. From Etymology to Pragmatics: Metaphorical and Cultural Aspects of Semantic Structure. Cambridge University Press

39. Tadjer A. Wenn unsere Träume Tango tanzen. Blanvalet Verlag. 2017. S.320

40. Thomas I. Latin Dance. Lerner Publications. 2011. p.32

\section{Перцептивные метафоры в репрезентации бальных танцев: кросскультурный подход \\ М. Седакова}

Аннотация. Цель данной статьи - выявить роль перцептивных метафор в репрезентации бальных танцев с помощью средств разных языков. В статье выявлены конкретные образы, релевантные для анализируемых дискурсов, которые представляют бальный танец ка сложное и многогранное явление, как неотъемлемый атрибут физического и эмоционального бытия, неотъемлемую часть культуры и творческой деятельности. Материал исследования охватывает более 200 контекстов, которые соотносятся с англоязычным, немецкоязычным и русскоязычным хореографическим дискурсом.

Ключевые слова: периептивная метафора, сравнительный метод, модальность, хореографический дискурс. 